\title{
A robust model for estimating standing crop across vegetation types
}

\author{
LANCE T. VERMEIRE, AMY C. GANGULI, AND ROBERT L. GILLEN
}

Authors are Rangeland Scientist, USDA-ARS, Fort Keogh Livestock and Range Research Laboratory, Miles City, Mont. 59301; and former Research Assistant, Department of Range, Wildlife, and Fisheries Management, Texas Tech University, Lubbock, Tex. 79409-2125; and Rangeland Scientist, USDA-ARS, Southern Plains Range Research Station, Woodward, Okia. 73801.

\section{Abstract}

Some recent investigations have shown the visual obstruction (VO) measurement method to be an effective means of estimating herbage standing crop non-destructively in tallgrass prairie. Although the method is rapid and inexpensive, visual obstruction models have been limited to tallgrass prairie and sandhills range types. Our primary objective was to evaluate the relationships between visual obstruction and standing crop in shortgrass plains and mixed prairie. Secondly, we wanted to determine whether these models could be integrated with tallgrass prairie models without appreciable losses in prediction capabilities. We conducted 44 trials on non-burned sites with various levels of grazing pressure. Each trial was composed of 20 randomly selected plots and served as 1 experimental unit to represent pasturelevel standing crop estimation. Visual obstruction readings were taken from a modified Robel pole placed centrally at the back of $0.1-\mathrm{m}^{2}$ quadrats and vegetation was clipped to estimate standing crop. Trial standing crop was regressed on visual obstruction and models were compared among range types. Visual obstruction explained 91 and $89 \%$ of the variation in shortgrass plains and mixed prairie standing crop, respectively. A single visual obstruction model effectively estimated herbage standing crop across range types and produced a coefficient of determination of 0.93. Although greater precision may be obtained from models developed for specific sites, the ability of a single visual obstruction model to predict standing crop across years, management schemes, and range types indicates visual obstruction models may be successfully employed on a regional basis.

Key Words: mixed prairie, non-destructive sampling, Robel pole, shortgrass, tallgrass

Herbage standing crop is commonly monitored on rangelands to determine stocking capacity and effects of management or experimental treatments. Measurements are typically made by clipping vegetation from randomly-placed quadrats and extrapolating dry weight over the area of interest. Clipping can provide accurate and precise estimates, but the time and labor required often prevent researchers and managers from clipping or collecting an adequate number of samples.

Indirect methods have been tested to simplify standing crop estimation, but accuracy is generally sacrificed and the applicability of individual models is typically limited relative to direct

This is manuscript T-9-893 of the College of Agricultural Sciences and Natural Resources, Texas Tech University.

Manuscript accepted 17 Dec. 01.

\section{Resumen}

Recientes investigaciones han mostrado el método de medida de obstrucción visual (VO) como un medio efectivo y no-destructivo para la estimación de la produccion de forraje en pastazales de zacates altos. Aunque el mé todo es rapido y barato, los modelos de VO han sido limitados a pastizales de zacates altos y pastizales de colinas arenosas. Nuestro objectivo principal fué evaluar la relación entre VO y la producción de forraje en pastizales de zacates cortos y pastizales mediano abierto. También quisimos determinar si estos modelos pudieran ser integrados a los modelos de pastizal de zacates altos sin perdida apreciable en la capacidad de predicción. Se realizaron 44 muestreos en sitios noquemados con diferentes niveles de carga animal. Cada muestreo qu sirvió como la parcela experimental consistió de 20 parcelas seleccionadas al azar, representando la estimación de producción de forraje en cada nivel. Las lecturas de VO fueron tomadas desde un poste Robel modificado colocado en el centro atrás de los quadrantes de $0.1 \mathrm{~m}^{2}$ y se realizaron cortes para estimar la produccion de forraje. La producción de forraje de los muestreos fué analizada con datos de VO a través de regresion y los modelos fueron comparados entre ipos de pastizal. Un modelo estimó efectivamente la producción de forraje a través de tipos de pastizal, con coeficiente de determinación de 0.93 . La habilidad de un solo modelo VO para predecir productividad a través de los años, esquemas de manejo, y tipos de pastizal indica que modelos VO puede ser empleado exitosamente en una base regional.

measurements (Michalk and Herbert 1977, Gonzalez et al. 1990, Catehpole and Wheeler 1992, Hannoney et al. 1997). Visual obstruction (VO) measurements were highly correlated with standing crop in homogeneous tallgrass communities (Robel et al. 1970). Vermeire and Gillen (2001) also found VO measurements to improve sampling efficiency and effectively estimate standing crop year-round in heterogeneous tallgrass prairie, across seral stages and levels of standing crop.

Evaluation of the VO method has been limited to tallgrass prairie, sandhills, and sandy lowland range types. Higgins et al. (1996) suggested the method would not provide useful information in shortgrass plains or sparsely vegetated habitats. Volesky et al. (1999) also stated that the VO method was of limited utility in sandhills vegetation. However, the VO method was successfully employed on sandy lowlands in Nebraska (Benkobi et al. 2000) and under a wide array of conditions in southern tallgrass prairie (Vermeire and Gillen 2001), suggesting the method may 
be applicable for pasture standing crop estimation in other vegetation types.

Our objectives were to evaluate the relationships between $\mathrm{VO}$ and standing crop in shortgrass plains and mixed prairie and determine whether these models could be integrated with a tallgrass model to produce a more universal equation (Vermeire and Gillen 2001) without appreciable loss in pasture-level prediction capabilities.

\section{Methods and Materials}

\section{Study Areas}

Shortgrass plains trials were conducted from July through August 1999 in Armstrong County, Tex. ( $35^{\circ} 10^{\prime} \mathrm{N}, 101^{\circ} 0$ $15^{\prime} \mathrm{W}$, elevation $975 \mathrm{in}$ ). The climate is dry steppe with an average frost-free growing period of 181 days. Mean annual precipitation is $505 \mathrm{~mm}$ with $75 \%$ occurring from April to September (NOAA 1998). Sampling was conducted on deep hardland and shallow range sites with Pullman silty clay loam (Fine, mixed, superactive, thermic Torrertic Paleustolls) and Potter soils (Loamy-skeletal, carbonatic, thermic Petronodic Ustic Haplocalcids), respectively (Jacquot et al. 1965). The area was moderately stocked with cows and calves under a continuous yearlong grazing system.

Dominant grasses were buffalograss [Buchloe dactyloides (Nutt.) Engelm.] and blue grama [Bouteloua gracilis (H.B.K.) Lag. ex Steud], with threeawns (Aristida spp. L.), and sideoats grama [Bouteloua curtipendula (Michx.)Torr.] as secondary components. Dominant forbs included woolly plantain (Plantago patagonica Jacq.), prairie coneflower [Ratibida coIumnifera (Nutt.) Woot. \& Standl.], annual broomweed [Amphiachyris dracunculoides (DC.) Nutt. ex Rydb.], and broom snakeweed [Gutierrezza sarothrae (Pursh) Britt. \& Rusby]. More than $80 \%$ of the biomass was comprised of blue grama and buffalograss.

Mixed prairie data were collected from June through August 1999 in Lubbock County, Tex. $\left(33^{\circ} 35^{\prime} \mathrm{N}, 101^{\circ} 53^{\prime} \mathrm{W}\right.$, elevation $990 \mathrm{~m}$ ). The climate is dry steppe with an average frost-free growing period of 210 days. Mean annual precipitation is $450 \mathrm{~mm}$ with $67 \%$ of the precipitation occurring from May to September (NOAA 1998). Sampling was conducted on clay loam and sandy loam range sites with Acuff (Fine-loamy, mixed, superactive, thermic Aridic Paleustalfs) and Amarillo (Fine-loamy, mixed, superactive, thermic Aridic Paleustalfs) soils (Blackstock 1979). Vegetation on the study area had not been grazed by large herbivores since November 1982, but some of the areas had been mowed.

Dominant grasses included blue grama, purple threeawn (Aristida purpurea Nutt.), silver bluestem [Bothriochloa laguroides (DC.) Herter], and buffalograss. Other common midgrasses included sand dropseed [Sporobolus cryptandrus (Torr.) Gray], Arizona cottontop [Digitaria californica (Benth.) Henr], vine mesquite (Panicum obtusum H.B.K.), and sideoats grama. Blueweed sunflower [Helianthus ciliaris DC.], prairie coneflower, and lambsquarters (Chenopodium album L.) were the dominant forbs.

Tallgrass prairie trials were conducted in Payne County, Okla. ( $36^{\circ} 04^{\prime} \mathrm{N}, 97^{\circ} 13^{\prime}$ $\mathrm{W}$, elevation $280 \mathrm{~m}$ ) from 1994 to 1996 (Vermeire and Gillen 2001). The continental climate allows a 204-day frost-free growing season from April to October. Mean annual precipitation is $831 \mathrm{~mm}$, with $65 \%$ falling as rain from May to October (Myers 1982). Range sites sampled included sandy savannah, loamy prairie, shallow prairie, and eroded prairie. All sites were exposed to cattle grazing at various stocking rates under short-duration, intensive-early stocking, and continuous season-long grazing systems.

Dominant grasses were big bluestem (Andropogon gerardii Vitman), little bluestem, Indiangrass [Sorghastrum nutans (L.) Nash], and tall dropseed [Sporobolus asper (Michx.) Kunth]. Western ragweed (Ambrosia psilostachya DC.) and annual broomweed were the dominant forbs. Grama grasses (Bouteloua spp. Lag.), annual threeawn (Aristida oligantha Michx.), and forbs were more prominent on sites in lower seral stages.

\section{Methods}

We conducted 44 trials on non-burned sites in mixed prairie $(n=24)$ and shortgrass plains $(n=20)$ over a wide array of standing crops and species composition. Plant phenology was also variable among trials because data were collected weekly from June through August, covering earlyleaf to mature plant stages. Each trial consisted of 20 individual plots $(20 \times 50-\mathrm{cm}$ quadrats) arranged systematically along pace transects, with approximately $15 \mathrm{~m}$ between plots.

Visual obstruction was measured with a visual obstruction pole (Robel et al. 1970). The measurement pole was a wooden dowel $(2.5 \times 100 \mathrm{~cm})$ marked with alternating red and white decimeter bands. The pole also was marked with black lines every $2 \mathrm{~cm}$. A second wooden dowel (1 x
$100 \mathrm{~cm}$ ) was attached to the measurement pole by a 4-m string to maintain a consistent observation point. The visual obstruction pole was placed centrally at the distant short side of each $20 \times 50$-cm quadrat and observed from a distance of $4 \mathrm{~m}$ and a height of $1 \mathrm{~m}$. A single reading was taken at each plot by recording the height of the lowest visible black mark. All vegetation rooted in the plot was then clipped to ground level and oven-dried to a constant weight at $55^{\circ} \mathrm{C}$ to determine standing crop.

Relationships between standing crop and visual obstruction were determined by regression analysis, using trial means as observations (SAS 1985). Trials were selected as experimental units to address the objective of assessing pasture-level standing crop estimation and to reduce bias created by relating visual obstruction (VO) to quadrats of fixed dimensions (Vermeire and Gillen 2001). Indicator regression was used to identify differences in models by range type (Neter et al. 1990). Root mean squared errors (RMSE) were used to assess model accuracy and model precision was evaluated by constructing 95\% confidence intervals (Zar 1974). Prediction intervals were calculated for future observations and means of 2,4 , and 6 future observations to indicate with $95 \%$ confidence the intervals within which future users of the models may expect their true values to lie relative to model predictions (Neter et at 1990). Smallest, largest, and mean maximum estimate errors are provided to indicate the range and mean differences between estimates and limits for confidence intervals and prediction intervals.

\section{Results and Discussion}

Trial standing crop ranged from 1,820 to $5,360 \mathrm{~kg} \mathrm{ha}^{-1}$ in mixed prairie and 800 to $1,990 \mathrm{~kg} \mathrm{ha}^{-1}$ in shortgrass plains. Visual obstruction (VO) was positively related to standing crop and explained at least $89 \%$ of the variation in standing crop for mixed prairie $(\mathrm{P}<0.01)$ and shortgrass plains $(\mathrm{P}$ $<0.01$, Fig. 1). Similar results were obtained in non-burned tallgrass prairie (Robel et al. 1970, Vermeire and Gillen 2001) and a sandy lowland range site (Benkobi et al. 2000). The accuracy of both models would comply with most management and research needs (Table 1). Confidence intervals indicated the true mean standing crop at any level of VO within our range of data would be expected to occur within $121 \mathrm{~kg} \mathrm{ha}^{-1}$ of our esti- 


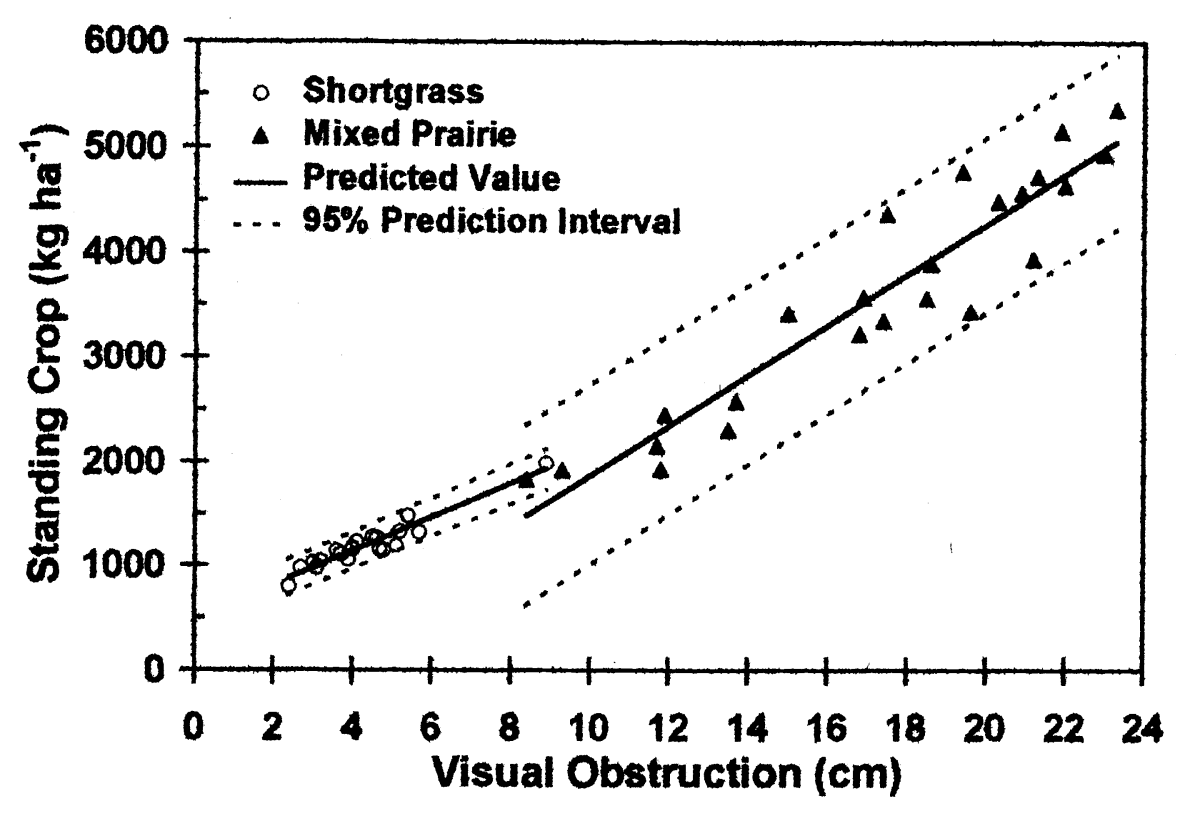

Fig. 1. Relationships between standing crop and visual obstruction in shortgrass plains and mixed prairie and $95 \%$ prediction intervals for single future observations.

mate in shortgrass plains and $365 \mathrm{~kg} \mathrm{ha}^{-1}$ in mixed prairie.

Prediction intervals showed with $95 \%$ confidence that the true standing crop for any single trial observation made in the future would be expected to occur within $197 \mathrm{~kg} \mathrm{ha}^{-1}$ of the shortgrass model estimates and within $864 \mathrm{~kg} \mathrm{ha}^{-1}$ of mixed prairie model estimates (Fig. 1). Although both models were accurate and the estimated values were precise, reliable estimates may not be expected with a single future trial.

As with any sampling, increasing sample size will increase confidence in estimates and reduce the size of intervals within which future observations are expected to lie. Vermeire and Gillen (2001) determined 6 VO measurements could be taken in the time required to clip 1 plot. Randomly taking 6 times as many VO readings over the same area would closely approximate the mean of 6 trials and reduce mean maximum estimate errors for predicted values to about $79 \mathrm{~kg}$ $\mathrm{ha}^{-1}$ in shortgrass plains and $390 \mathrm{~kg} \mathrm{ha}^{-1}$ in mixed prairie (Table 2). It is important to recall future data are independent of the data used in the construction of our models and have no effect on model accuracy or precision. Prediction intervals simply provide a measure of expected precision for samples collected in the future.

Prediction model differences occurred among range types $(P=0.02)$. Tallgrass and shortgrass models were very similar. The mixed prairie model differed from the tures that had not been grazed or burned for 17 years. The accumulation of standing dead in rested or lightly stocked pastures would increase the herbage mass per unit of visual obstruction. Vermeire and Gillen (2001) showed that the amount of herbage per $\mathrm{cm}$ of visual obstruction is reduced on burned sites because much or all of the standing dead vegetation is consumed by fire. Similar effects may occur in heavily grazed pastures if limited amounts of standing dead are retained between years. The slope of our mixed prairie model was nearly identical to that obtained by Benkobi et al. (2000), but the management history of their sites was not stated. Despite the model differences among range types, prediction capabilities were maintained after combining data from pastures in tallgrass prairie, mixed prairie, and shortgrass plains (Fig. 2). A single model explained $93 \%$ of the variation in standing crop across range types and produced a root mean squared errors (RMSE) of $380 \mathrm{~kg} \mathrm{ha}^{-1}(\mathrm{P}<0.01)$. The model containing only tallgrass data had a coefficient of determination of 0.90 and a RMSE of $418 \mathrm{~kg} \mathrm{ha}^{-1}$ (Vermeire and Gillen 2001). Because error variances were heterogeneous for the combined model, meaningful confidence intervals and prediction intervals could not be calculated. However, the high coefficient of determination and small standard error for the slope (5.72) indicate the model will pro-

Table 1. Visual obstruction regression coefficients and statistics for shortgrass plains and mixed prairie.

\begin{tabular}{lcc}
\hline \hline & Shortgrass plains $(\mathrm{n}=20)$ & Mixed prairie $(\mathrm{n}=24)$ \\
\hline Slope & $162(12) \mathrm{a}$ & $240(18)$ \\
Intercept $^{\mathrm{b}}$ & $496(55)$ & $-535(318)$ \\
Root mean square error $_{\text {Coefficient of determination }\left(\mathrm{r}^{2}\right)}$ & 74 & 378 \\
Maximum estimate error ${ }^{\mathrm{c}}$ & & \\
Smallest & 35 & 160 \\
Largest & 121 & 365 \\
Mean & 46 & 219 \\
\hline
\end{tabular}

${ }^{\mathrm{a}}$ Standard errors for regression coefficients are in parentheses.

${ }^{\mathrm{b}}$ The intercept for the mixed prairie model did not differ from $0(\mathrm{P}=0.11)$.

${ }^{c}$ Range and mean maximum estimate errors were calculated from $95 \%$ confidence intervals.

Table 2. Maximum estimate errors from $95 \%$ prediction intervals on shortgrass plains and mixed prairie visual obstruction models at various sampling intensities.

\begin{tabular}{lcccccc}
\hline \hline & \multicolumn{3}{c}{ Shortgrass plains } & \multicolumn{3}{c}{ Mixed prairie } \\
& Smallest & Largest & Mean & Smallest & Largest & Mean \\
\hline Single trial & 160 & 197 & 164 & 799 & 864 & 815 \\
2-trial mean & 116 & 164 & 120 & 576 & 663 & 598 \\
4-trial mean & 86 & 144 & 91 & 423 & 536 & 451 \\
6-trial mean & 73 & 137 & 79 & 357 & 486 & 390 \\
\hline
\end{tabular}

${ }^{\mathrm{a}}$ Difference between estimate and confidence limit from $95 \%$ prediction intervals. 


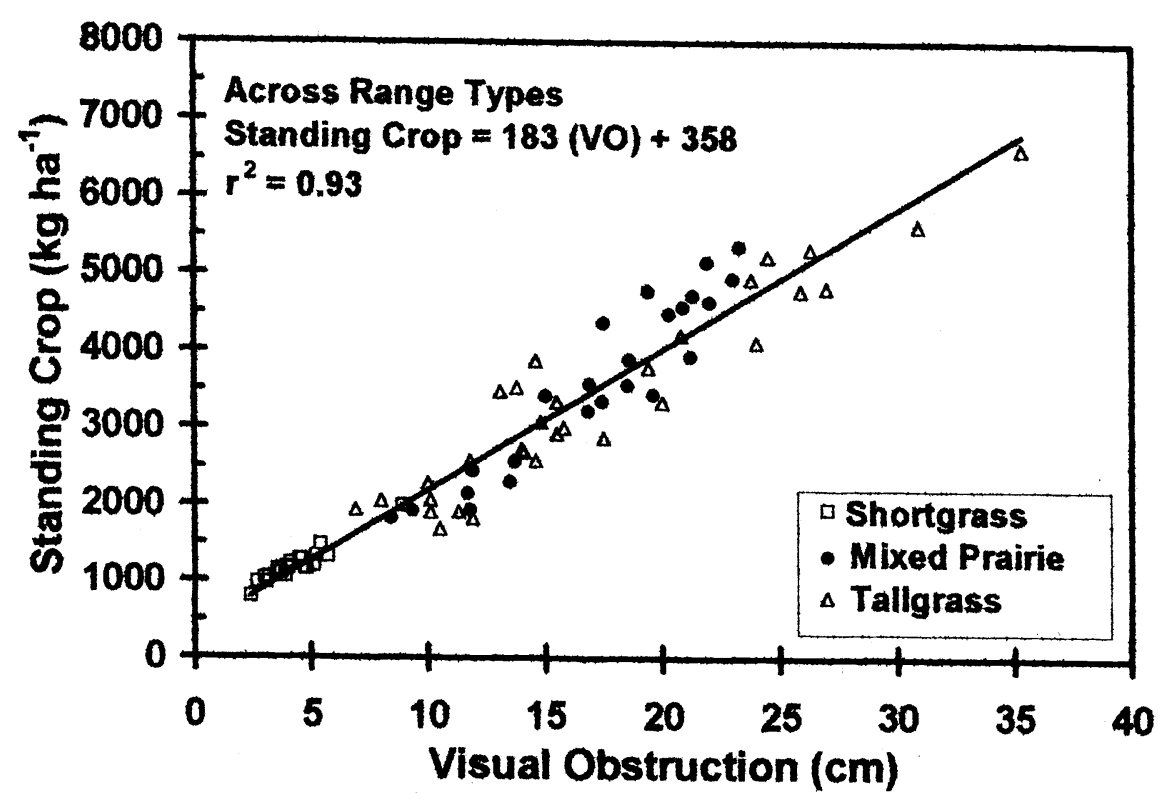

Fig. 2. Relationship between standing crop and visual obstruction across tallgrass prairie, mixed prairie, and shortgrass plains vegetation types.

vide reliable estimates, given adequate sampling.

Visual obstruction (VO) has generally been a good predictor of herbaceous standing crop (Robel et al. N 1970, Benkobi et al. 2000, Ganguli et al. 2000, Vermeire and Gillen 2001). However, Volesky et al. (1999) had coefficients of determination of 0.31 to 0.41 in Nebraska sandhills vegetation and found no improvement by using trial means as observations. We believe differences among studies can be attributed to sampling procedures. Vermeire and Gillen (2001) found that the area truly measured by $\mathrm{VO}$ is 3 -dimensional and variable among points. This source of variation in model development can be reduced by designing quadrats to measure only the vegetation affecting the $\mathrm{VO}$ reading and by using means of $\mathrm{VO}$ readings and clipped estimates as observations. Researchers using rectangular quadrats with the obstruction pole placed at the distant short side have found strong relationships between VO and standing crop using trial means as observations and taking a single reading per quadrat (Robel et al. 1970, Ganguli et al. 2000, Vermeire and Gillen 2001). Those using circular quadrats with the obstruction pole placed centrally have obtained poorer results unless multiple readings were taken from various angles around each quadrat (Volesky et al. 1999, Benkobi et al. 2000).

We found the combined and individual range type models to be accurate. Selecting the appropriate model will depend on the objectives of the user and the characteristics of their sites. Visual obstruction models are expected to be more accurate and precise if they are developed for individual range types or specific sites, given equal sample size. However, the general applicability of a model is reduced as the associated conditions of that model become more discrete. One advantage of a combined model across range types is that it could be used to estimate standing crop on sites with multiple or interspersed range types. Additionally, a combined model may facilitate use of the VO method for user groups that operate on a regional basis by providing a single universal equation.

Our combined model effectively predicted standing crop year-round across multiple years, range types, range sites, seral stages, and management systems. If greater precision is desired, we recommend increasing sample size, or developing models specific to the location or conditions of interest using the methodology of Vermeire and Gillen (2001).

\section{Literature Cited}

Benkobi, L., D. W. Uresk, C. Schenbeck, and R. M. King. 2000. Protocol for monitoring standing crop in grasslands using visual obstruction. J. Range Manage. 53:627-633.

Blackstock, D. A. 1979. Soil Survey of Lubbock County, Texas. USDA, Soil Conserv. Serv., Washington, D.C.
Catchpole, W. R. and C. J. Wheeler. 1992. Estimating plant biomass: a review of techniques. Australian J. Ecol. 17:121-131.

Ganguli, A. C., L. T. Vermeire, R. B. Mitchell, and M. C. Wallace. 2000. Comparison of four nondestructive techniques for estimating standing crop in shortgrass plains. Agron. J. 92:1211-1215.

Gonzalez, M. A., M. A. Hussey, and B. E. Conrad. 1990. Plant height, disk, and capacitance meters used to estimate bermudagrass herbage mass. Agron. J. 82:861-864.

Harmoney, K. R., K. J. Moore, J. R. George, E. C. Brummer, and J. R. Russell 1997. Determination of pasture biomass using four indirect methods. Agron. J. 89:665-672.

Higgins, K. F., J. L. Oldemeyer, K. J. Jenkins, G. K. Clanibey, and R. F. Harlow. 1996. Vegetation sampling and measurement, p. 567-591. In: T. H Bookhout (ed.), Research and management techniques for wildlife and habitats. The Wildlife Society, Bethesda, Md.

Jacquot, L. L., L. C. Geiger, B. R. Chance, V. D. Woods, D. A. Leath, and L. C. Imke. 1965. Soil Survey of Armstrong County, Texas. USDA, Soil Conserv. Serv., Washington, D.C.

Michalk, D. L. and P. K. Herbert. 1977. Assessment of four techniques for estimating yield on dryland pastures. Agron. J. 69:864-868.

Myers, H.R. 1982. Climatological data of Stillwater Oklahoma 1893-1980. Oklahoma Agr. Exp. Sta. Res. Rep. 821. Stillwater, Okla.

National Oceanic and Atmospheric Administration. 1998. Climatological data annual summary. Texas. Vol. 103, No. 13.

Neter, J., M. H. Kutner, C. J. Nachtscheim, and W. Wasserman. 1990. Applied linear regression analysis. Richard D. Irwin, Chicago, Ill.

Robel, R. J., J. N. Briggs, A. D. Dayton, and L. C. Hulbert. 1970. Relationships between visual obstruction measurements and weight of grassland vegetation. J. Range Manage. 23:295-297.

SAS Institute. 1985. SAS/STAT Guide for personal computers, Version 6 edition. Cary, N.C.

Vermeire, L. T. and R. L. Gillen. 2001. Estimating herbage standing crop with visual obstruction in tallgrass prairie. J. Range Manage. 54:57-60.

Volesky, J. D., W. H. Schacht, and P. E. Reece. 1999. Leaf area, visual obstruction, and standing crop relationships on Sandhills rangeland. J. Range Manage. 52:494-499.

Zar, J. H. 1974. Biostatistical analysis. Prentice-Hall, Inc., Engelwood Cliffs, N.J. 